\title{
Metal Contamination in Ground Water of Dang District
}

\author{
Rajendra K. Mahat ${ }^{1}$ and Rashmi Shrestha ${ }^{2}$ \\ ${ }^{I}$ Department of Water Supply and Sewerage, Kathmandu, Nepal \\ ${ }^{2}$ Kathmandu University, Dhulikhel
}

\begin{abstract}
Drinking water quality in Nepal has been an issue of prevalent concern. So, this study was conducted to visualize the scenario of metal contamination in ground water of Dang district located at central west Terai in Nepal. A total of 523 water samples from tubewells and dugwells positioned in 16 village development committees (VDCs) were tested for arsenic in laboratory using atomic absorption spectrophotometer (AAS) employing continuous flow hydride generation technique. Randomly selected 20 samples were also tested for other heavy and trace metals like $\mathrm{Mn}, \mathrm{Fe}, \mathrm{Cu}$, and $\mathrm{Cd}$ using AAS employing flame method. Of the total samples, 50.3\% was found to contain arsenic above WHO drinking water qualty guidelines value of $10 \mathrm{ppb}(0.01 \mathrm{mg} / \mathrm{l})$ and $10.7 \%$ was found to contain arsenic above national drinking water quality guidelines value of $50 \mathrm{ppb}(0.05 \mathrm{mg} / \mathrm{l})$. The safest VDC is Sonpur while the most severely affected VDC is Gobardiha. A highest concentration of As of $240 \mathrm{ppb}(0.24 \mathrm{mg} / 1)$ was found in Dhikpur VDC. Ground water in this area seemed to be affected by high concentration of iron up to $11.01 \mathrm{mg} / \mathrm{l}$ and of manganese up to $0.51 \mathrm{mg} / \mathrm{L}$. Statistical tools were employed to assess the probable association among metals but no significant correlation could be retrieved.
\end{abstract}

Key words: hydride generation-atomic absorption spectrophotometry, redox conversion, arsenicosis, heavy and trace metals

\section{Introduction}

Water is life but when contaminated, can be a cause of death. Regarding this fact, water quality has become a burning issue globally and so does in Nepal. Of the myriads of contaminants, metals, especially heavy and trace, engender serious health hazards in human and animals when present and consumed in higher concentration. Arsenic is a contaminant present pervasively in high concentration in ground water $(\mathrm{GW})$ of Terai belt of Nepal. Opting this, the study was mainly focused on assessment of arsenic contamination in Dang District. Other metal contaminants like $\mathrm{Fe}, \mathrm{Cu}, \mathrm{Mn}$, and Cd were also assessed simultaneously.

Arsenic is a metalloid presented at the group 15 of the modern periodic table. Physically, arsenic occurs in many allotropic forms and in oxidation states of -III (as in $\mathrm{AsH}_{3}$ ), + III (as arsenites) and +V (as arsenates, most stable form). Penta and trivalent forms undergo redox conversion which makes its availability in the environment more abundant. It forms colourless, tasteless, and odorless crystalline oxides $\mathrm{As}_{2} \mathrm{O}_{3}$ and $\mathrm{As}_{2} \mathrm{O}_{5}$ which being hygroscopic dissolve readily in water to form weak arsenic $(\mathrm{V})$ acid $\left(\mathrm{H}_{3} \mathrm{AsO}_{4}\right)$. Arsenic is highly toxic element and regarded as the king of poisons. Chemically, it is found in both organic and inorganic forms and the latter is more toxic and the trivalent form is more noxious. International Agency for Research in Cancer (IARC) has identified it as a group 1 carcinogen. WHO (1993) has recommended a tolerable concentration of arsenic to be $10 \mathrm{ppb}(0.01 \mathrm{mg} / \mathrm{l})$ and Nepal Government in 2006 has formulated a National Drinking Water Quality Guidelines which has set the maximum concentration of arsenic in drinking water to be $50 \mathrm{ppb}$ (0.05 mg/l).

Arsenic is profusely distributed in earth's crust (52nd in abundance) in the form of minerals viz. arsenopyrite, realgar $\left(\mathrm{As}_{4} \mathrm{~S}_{4}\right)$, and orpiment $\left(\mathrm{As}_{2} \mathrm{~S}_{3}\right)$, etc. Due to weathering and other process like fragmentation of arsenic rich rocks and minerals it is introduced to water, ground water, and soil and sediments. Ground water in Indian sub-continent, especially Bangladesh, West Bengal (India) and Terai belt of Nepal, is sternly contaminated with arsenic. Although arsenic is essential to human body in ultra trace amount, it is physiologically highly deleterious if consumed in high concentration. Concentration of arsenic in $100 \mathrm{ppb}$ is considered to have lethal impact on human as well as animal health. Arsenic being an effective carcinogen 
causes keratosis, and melanoma and in severe cases arsenicosis. It is the condition in which arsenic is deposited to skin, hair, and nails where it is firmly bounded to keratin. It also has teratogenic effect. If consumed in high concentration for prolonged period, it may also be found in liver, kidney, spleen, and lungs as well. This eventually can lead to severe renal and pulmonary dysfunction and even skin cancer.

Sometimes, arsenic may be associated with some other heavy and trace metal contaminants like cadmium, manganese, iron, copper etc. Their presence in intolerable limits can produce even more rigorous effects upon human health. For instance, cadmium is highly deleterious for kidney and other vital organs and may even cause genetic mutation. Prolonged consumption of high concentration of cadmium may ultimately lead to death. Likewise, manganese in high concentration is found to be associated with nervous system disorder. Copper, in high concentration, may prove to be dangerous to infants (Lee 1999). Concerning these facts, a research was conducted to assess the presence of probable contaminants along with arsenic.

In lieu their impact on human health, iron and manganese when present in high concentration in ground water have tendency of reducing arsenic concentration by the phenomenon like coprecipitation and adsorption.

\section{Materials and Methods}

Among 41 VDCs in Dang district, 523 water samples of tube wells and dug wells from16 VDCs were tested at the Central Drinking Water Quality Testing Laboratory, Department of Water Supply and Sewerage (DWSS). Moreover, out of 523 samples, 20 samples were chosen randomly and administered to analyze other metal parameters like iron, copper, manganese, and cadmium.

\section{Sample collection}

Water samples were collected in the field in acid rinsed polythene bottle of capacity $125 \mathrm{ml}$. About 1 $\mathrm{ml}$ of concentrated hydrochloric acid of analytical grade, just enough to adjust sample $\mathrm{pH}$ below 2, was used to preserve the sample and transported to the central laboratory of DWSS.

\section{Analytical procedure}

In laboratory, water samples were analyzed by AAS (Thermo SOLAAR) employing continuous flow hydride generation technique for arsenic and other parameters were tested by simple flame method. All the analyses were carried out adopting standard methods of analysis formulated by (American Public Health Association (APHA) and National Arsenic Steering Committee (NASC). Chemicals and reagents used in the analysis were of analytical grade, double distilled water was used for solution preparation. Water samples, for testing arsenic, were pretreated prior to analysis adding $5 \mathrm{ml}$ each of concentrated $\mathrm{HCl}$ and $10 \%(\mathrm{v} / \mathrm{v}) \mathrm{NaI}$ and kept for about 20 minutes. On the other hand, water samples were kept for acid digestion for analysis of other metals. Linear calibration curve method using three standard metal solutions was employed to carry out the analysis.

\section{Chemistry of arsenic analysis}

In $50 \mathrm{ml}$ of a sample $5 \mathrm{ml}$ each of conc. $\mathrm{HCl}$ and $10 \% \mathrm{w} / \mathrm{v} \mathrm{NaI}$ are added. As a result, all arsenic species, both $\mathrm{As}(\mathrm{III})$ and $\mathrm{As}(\mathrm{V})$, are converted into arsenic (III) tri-Iodide which on reaction with $0.5 \%$ sodium borohydride $\left(\mathrm{NaBH}_{4}\right)$ solution in acidic medium $(50 \% \mathrm{v} / \mathrm{v} \mathrm{HCl})$ gives arsine gas $\left(\mathrm{AsH}_{3}\right)$. Arsine is stable kinetically but not thermodynamically. So, it readily changes to arsenic in flame which gives absorbance at $193.7 \mathrm{~nm}$.

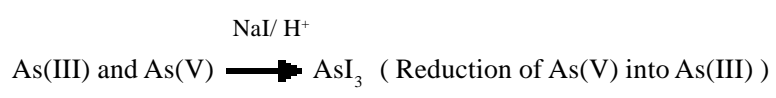

$4 \mathrm{AsI}_{3}+3 \mathrm{NaBH}_{4} \stackrel{\mathrm{H}^{+}}{-} 4 \mathrm{AsH}_{3}+3 \mathrm{NaI}+3 \mathrm{BI}_{3}$ (Arsine Generation)

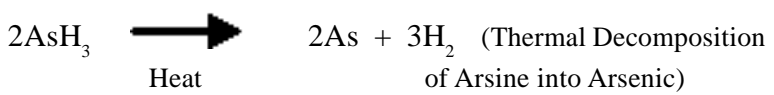

\section{Results and Discussion}

A total of 523 ground water samples from 16 VDCs were tested for arsenic in DWSS laboratory. Of them, $49.7 \%$ was found to be within $10 \mathrm{ppb}$ concentration ie safe, $39.6 \%$ of them were found to contain arsenic concentration in the range $11-50 \mathrm{ppb}$ which is above WHO tolerable limit and $10.7 \%$ was found to contain arsenic concentration more than $50 \mathrm{ppb}$ violating National Drinking Water Quality Guidelines Value for arsenic. A case of severe arsenicosis was identified in Bela VDC. (Table 1) 
R. K. Mahat \& R. Shrestha/Metal contamination in Ground Water........

Table 1. Status of arsenic in 16 VDCs

\begin{tabular}{|c|c|c|c|c|c|c|c|c|c|}
\hline \multirow{3}{*}{$\begin{array}{l}\mathrm{S} \\
\mathrm{N} \\
\end{array}$} & \multirow[t]{3}{*}{ VDCs } & \multirow{3}{*}{$\begin{array}{l}\text { Total no. of } \\
\text { Samples }\end{array}$} & \multicolumn{6}{|c|}{ Concentration of arsenic in ppb } & \multirow{3}{*}{$\begin{array}{c}\text { Highest } \\
\text { conc } \\
\text { in } \\
\text { ppb }\end{array}$} \\
\hline & & & \multicolumn{2}{|l|}{$0-10$} & \multicolumn{2}{|c|}{$11-50$} & \multicolumn{2}{|c|}{$>50$} & \\
\hline & & & No. & $\%$ & No. & $\%$ & No. & $\%$ & \\
\hline 1 & Dhikpur & 50 & 13 & 26 & 28 & 56 & 9 & 18 & 240 \\
\hline 2 & Dharna & 40 & 14 & 35 & 18 & 45 & 8 & 20 & 183 \\
\hline 3 & Saudiyar & 39 & 15 & 38.5 & 24 & 61.5 & 0 & 0 & 47 \\
\hline 4 & Sonpur & 34 & 33 & 97 & 1 & 3 & 0 & 0 & 14 \\
\hline 5 & Chailahi & 30 & 27 & 90 & 2 & 6.7 & 1 & 3.3 & 51 \\
\hline 6 & Satbariya & 39 & 22 & 56.4 & 12 & 30.8 & 5 & 12.8 & 64 \\
\hline 7 & Rajpur & 40 & 1 & 2.5 & 29 & 72.5 & 10 & 25 & 79 \\
\hline 8 & Bela & 33 & 14 & 42.4 & 16 & 48.5 & 3 & 9.1 & 138 \\
\hline 9 & Gangaparspur & 42 & 22 & 52.4 & 20 & 47.6 & 0 & 0 & 40 \\
\hline 10 & Gadhwa & 37 & 4 & 10.8 & 30 & 81.1 & 3 & 8.1 & 77 \\
\hline 11 & Sishaniya & 25 & 22 & 88 & 3 & 12 & 0 & 0 & 49 \\
\hline 12 & Lalmatiya & 28 & 27 & 96.4 & 1 & 3.6 & 0 & 0 & 12 \\
\hline 13 & Gobardiha & 51 & 20 & 39.2 & 15 & 29.4 & 16 & 31.4 & 146 \\
\hline 14 & Others & 35 & 26 & 74.4 & 8 & 22.8 & 1 & 2.8 & 72 \\
\hline \multicolumn{2}{|c|}{ Total } & 523 & 260 & 49.7 & 207 & 39.6 & 56 & 10.7 & \\
\hline
\end{tabular}

$10.70 \%$ Above $50 \mathrm{ppb}$

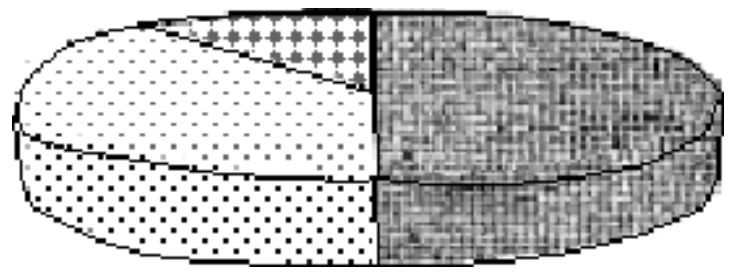

$49.70 \%$ upto $10 \mathrm{ppb}$

$39.60 \%$ in the range $11-50 \mathrm{ppb}$

Fig.1. Status of arsenic contamination in 16 VDCs

Of the 16 VDCs chosen for our study, Saudiyar, Sonpur, Gangaparaspur, Sishaniya and Lalmatiya were found to possess $100 \%$ safe tubewells (TW) and dugwells i.e. no well having arsenic concentration above $50 \mathrm{ppb}$. In Sonpur, 97\% of TWs and DWs were found to contain arsenic concentration upto $10 \mathrm{ppb}$. Gobardiha was the most affected VDC with $31.4 \%$ of wells contaminated with arsenic above $50 \mathrm{ppb}$ followed by Dhikpur with $18 \%$. Rajpur was the VDC possessing least percent of wells $(2.5 \%)$ containing arsenic concentration upto $10 \mathrm{ppb}$. Gadhwa, with $81.1 \%$, was the VDC with highest percent of well containing arsenic concentration in the range of 11$50 \mathrm{ppb}$.

Fig.1 depicts the overall status of arsenic contamination in VDCs chosen for research. 


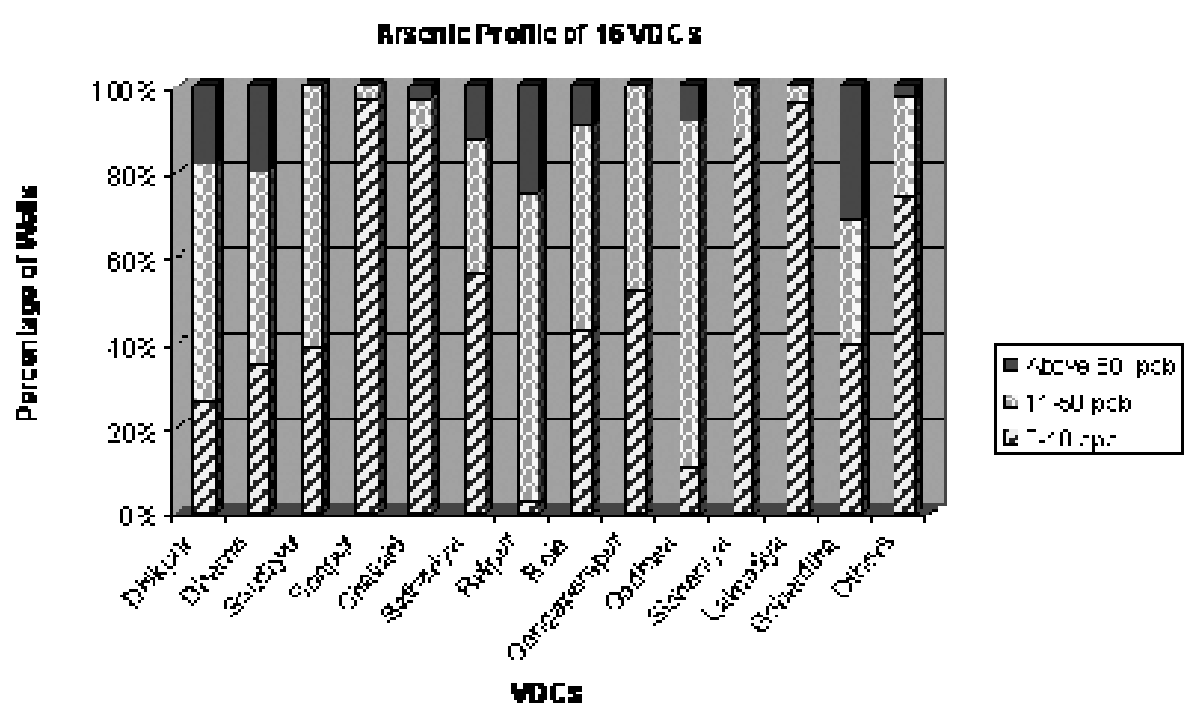

Fig. 2. Arsenic contamination profile of 16 VDCs

A graph of concentration of arsenic versus VDC was plotted. It exhibits: 4 VDCs namely Saudiyar, Sonpur, Gangaparaspur, and Lalmatiya contained highest arsenic concentration below 50 ppb; 5 VDCs viz. Chailahi, Satbariya, Rajpur, Gadhawa etc contained arsenic concentration between 50 and $100 \mathrm{ppb}$. On the other hand, rest of 4 VDCs were found to contain arsenic concentration above $100 \mathrm{ppb}$ with Dhikpur possessing the highest concentration of $240 \mathrm{ppb}$ followed by Dharna with 183 ppb.

Highest concentration of $\mathrm{As}$ (In ppb) In different VDCs

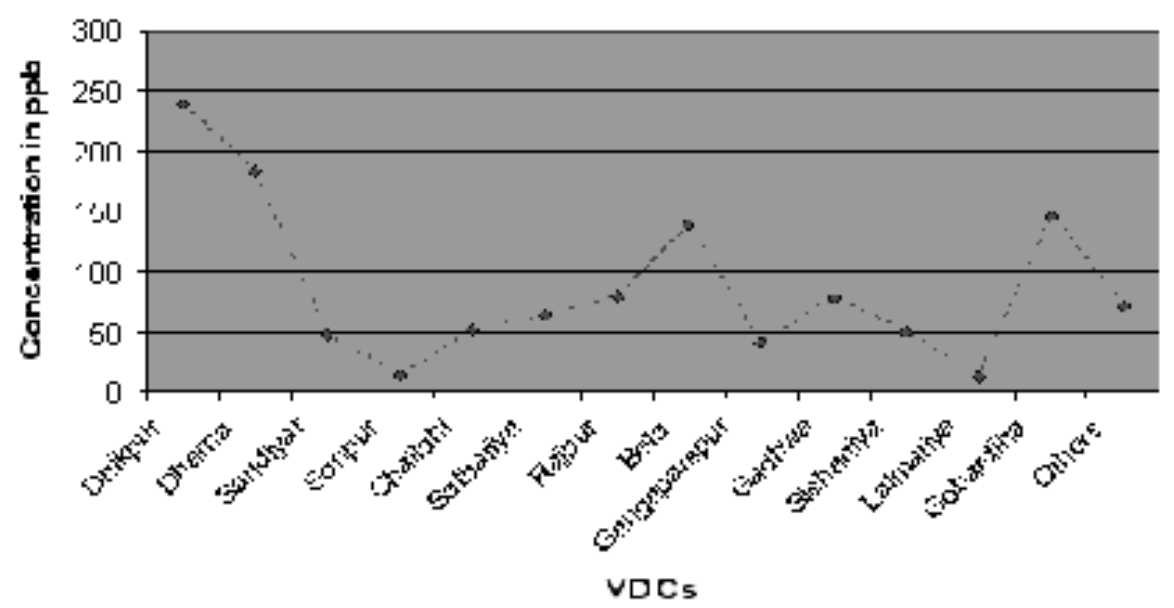

Fig 3. High concentration of arsenic in different VDCs

Among 523 samples brought to the central laboratory, 20 were selected randomly for the assessment of other probable heavy metal contaminants like iron, copper, manganese and cadmium. 
R. K. Mahat \& R. Shrestha/Metal contamination in Ground Water.

Table 2. AAS analysis of heavy and trace metal contaminants

\begin{tabular}{|c|c|c|c|c|c|c|}
\hline \multirow[t]{2}{*}{ S.N. } & \multirow[t]{2}{*}{ Sample ID } & \multicolumn{5}{|c|}{ Concentration of metals in $\mathrm{mgL}^{-1}$, analyzed by AAS } \\
\hline & & Arsenic & Iron & Copper & Manganese & Cadmium \\
\hline 1 & D-24 & 0.048 & 2.69 & 0.005 & 0.097 & 0.000 \\
\hline 2 & D-30 & 0.072 & 2.31 & 0.009 & 0.339 & 0.000 \\
\hline 3 & $\mathrm{D}-48$ & 0.016 & 0.13 & 0.006 & 0.000 & 0.000 \\
\hline 4 & D-50 & 0.046 & 2.72 & 0.000 & 0.037 & 0.000 \\
\hline 5 & D-73 & 0.045 & 2.29 & 0.008 & 0.052 & 0.000 \\
\hline 6 & D-75 & 0.032 & 3.01 & 0.010 & 0.079 & 0.000 \\
\hline 7 & D-135 & 0.014 & 1.93 & 0.000 & 0.513 & 0.001 \\
\hline 8 & D-147 & 0.028 & 2.17 & 0.005 & 0.126 & 0.000 \\
\hline 9 & D-219 & 0.001 & 0.50 & 0.024 & 0.000 & 0.000 \\
\hline 10 & D-227 & 0.000 & 0.15 & 0.015 & 0.000 & 0.000 \\
\hline 11 & D-240 & 0.001 & 0.63 & 0.020 & 0.000 & 0.000 \\
\hline 12 & D-243 & 0.0004 & 0.23 & 0.101 & 0.000 & 0.000 \\
\hline 13 & D-273 & 0.001 & 0.17 & 0.020 & 0.000 & 0.000 \\
\hline 14 & D-275 & 0.002 & 0.13 & 0.000 & 0.000 & 0.000 \\
\hline 15 & D-311 & 0.078 & 8.43 & 0.000 & 0.208 & 0.002 \\
\hline 16 & D-316 & 0.047 & 5.18 & 0.000 & 0.228 & 0.000 \\
\hline 17 & D-318 & 0.044 & 4.81 & 0.012 & 0.184 & 0.000 \\
\hline 18 & D-342 & 0.025 & 5.86 & 0.004 & 0.407 & 0.001 \\
\hline 19 & D-445 & 0.0004 & 0.17 & 0.000 & 0.000 & 0.000 \\
\hline 20 & D-509 & 0.047 & 11.01 & 0.0003 & 0.326 & 0.002 \\
\hline
\end{tabular}

Iron was found to be above Nepal water quality standard value of $0.3 \mathrm{mg} / 1$ in 14 samples with the highest concentration of $11.1 \mathrm{mg} / \mathrm{l}$, manganese (Nepal standard value: $0.2 \mathrm{mg} / \mathrm{l}$ ) in 6 samples with highest concentration of $0.513 \mathrm{mg} / \mathrm{L}$. Other metals viz. copper and cadmium were found to be within Nepal water quality standard values of $1.0 \mathrm{mg} / \mathrm{l}$ and $0.003 \mathrm{mg} / \mathrm{l}$ respectively.

Comparative plot of probable metal contaminants

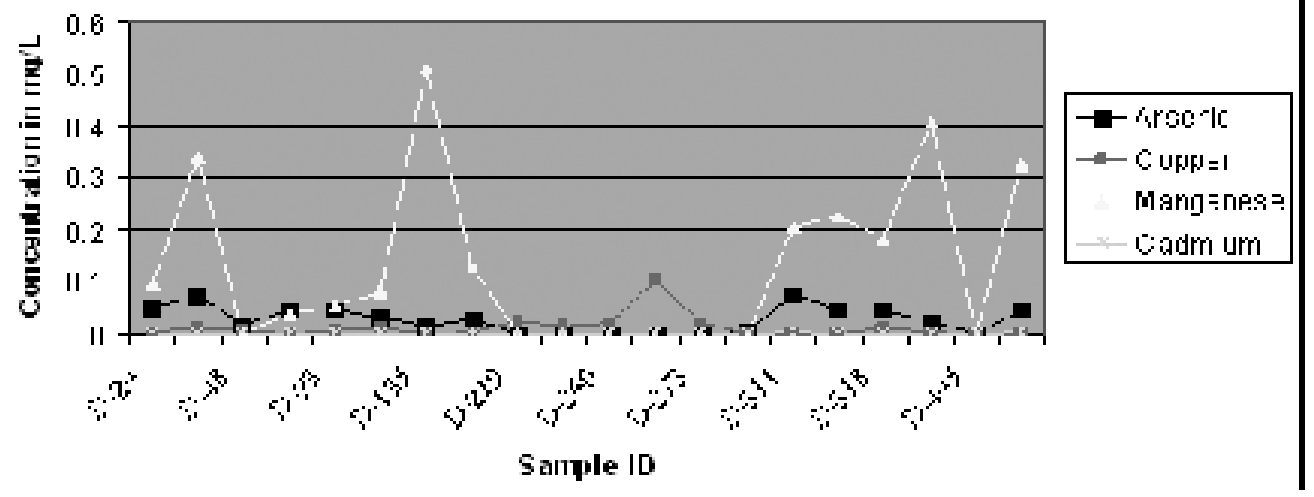

Fig. 4. Comparative concentration of four metals

Statistical tools were employed to ascertain probable correlation among these metals but no significant correlation was found

On the basis of this study, Dang district was found to be moderately affected by arsenic contamination in ground water with $10.7 \%$ of wells containing arsenic concentration transcending National Drinking Water Quality Standard Value of $50 \mathrm{ppb}(0.05 \mathrm{mg} / \mathrm{l})$. Specifically, Gobardiha was the most arsenic affected VDC. Conversely, Sonpur, Saudiyar, Gangaparaspur, and Sishaniya were the safest VDCs as per our study. 
Since arsenic is highly carcinogenic, possible means of mitigation should be promptly executed for the inhabitants of highly affected VDCs. Arsenic removal filters are the best option in household level. On the other hand, installation of deep tubewell may be the best mitigation option in community level. Prior to execution of mitigation options, public awareness programs should be launched to make people serious and concerned about the effects of arsenic in human and animal health. This will help establish mitigation program firmly and effectively.

Furthermore, other metals like iron and manganese were found to associate along with arsenic in high concentration. But the correlation among these metals could not be figured out in a significant manner as per our study. It might be due to inadequate sample size. So, in future, some large scale research can be conducted to find out such correlation. Such research may help not only to establish correlation among metal contaminants but also to locate arsenic safe source of drinking water as iron and manganese, when present in high concentration in ground water, may reduce the concentration of arsenic by the phenomenon of coprecipitation and adsorption.

\section{Acknowledgement}

The authors are highly indebted to Sen. Div. Er. A.K. Mishra, Chief Water Quality Section/DWSS, for heartening us to work in this research. Our special thanks are due to Mr. Ganga Dutta Nepal and Divisional Office of Dang for providing arsenic data of field test along with water samples in DWSS laboratory. All the laboratory and organizational staff who assisted in the analytical process and generation of data are highly appreciated for their role. We, cordially, want to acknowledge our friends Shankar Panta, Poonam Thapa, and M.R. Bhusal for helping and providing valuable suggestions throughout the development of this research paper.

\section{References}

DWSS/UNICEF 2002. A study on health effects of arsenic contaminated drinking water in Nawalparasi district, Nepal. A report, ENPHO, Kathmandu, Nepal.

APHA, AWWA, and WEF 2005. Standard methods for analysis of water and wastewater ( $21^{\text {st }}$ edition). APHA, Washington D. C.

Willard, H.H.and L.L. Merritt 1986. Instrumental methods of analysis ( $^{\text {th }}$ edition). CBS publishers, New Delhi, India.

Mendham, J.C., R.C. Denny et al. 2006. Vogel's textbook of quantitative chemical analysis( $6^{\text {th }}$ edition). Pearson Education Asia, Singapore.

Huheey, J E and E A Keiter 2000. Inorganic chemistry: Principles of structure and reactivity ( $4^{\text {th }}$ edition). Addison Wesley Publication Company, Menlo Park, California.

WHO. 2004. Guidelines for drinking water quality $\left(3^{\text {rd }}\right.$ edition) volume 1. World Health Organization, Geneva.

Lee, J.D. 1999. Concise inorganic chemistry ( $5^{\text {th }}$ edition). Blackwell Sciences Limited, India.

NASC. 2005. Summary of known arsenic occurrence in GW in Nepal as of December 2005. National Arsenic Steering Committee, Nepal.

Nicholas, N C. (1998). Chemistry of arsenic, antimony and bismuth. Springer. p. 50. ISBN9780751403893. http://books.google.de/ books?id=vVhpurkfeN4C. 